\title{
Composting of Food and Yard Wastes under the Static Aerated Pile Method
}

\author{
Gilberto Íñiguez-Covarrubias', Rodrigo Gómez-Rizo², Walter Ramírez-Meda ${ }^{3}$, \\ José de Jesús Bernal-Casillas ${ }^{3}$ \\ ${ }^{1}$ Departamento de Madera, Celulosa y Papel, Centro Universitario de Ciencias Exactas e Ingenierías, Universidad de Guadalajara, \\ Guadalajara, México \\ ${ }^{2}$ El Morado Compost, S.A. de C.V., Guadalajara, México \\ ${ }^{3}$ Departamento de Ingeniería de Proyectos, Centro Universitario de Ciencias Exactas e Ingenierías, Universidad de Guadalajara, \\ Guadalajara, México \\ Email: giniguez@dmcyp.cucei.udg.mx
}

How to cite this paper: Íñiguez-Covarrubias, G., Gómez-Rizo, R., Ramírez-Meda, W. and Bernal-Casillas, J. de J. (2018) Composting of Food and Yard Wastes under the Static Aerated Pile Method. Advances in Chemical Engineering and Science, 8, 271-279. https://doi.org/10.4236/aces.2018.84019

Received: July 21, 2018

Accepted: October 16, 2018

Published: October 19, 2018

Copyright $\odot 2018$ by authors and Scientific Research Publishing Inc. This work is licensed under the Creative Commons Attribution International License (CC BY 4.0).

http://creativecommons.org/licenses/by/4.0/

\begin{abstract}
This work presents the results that were obtained in a commercial composting plant where food $(149,690 \mathrm{~kg})$ and yard wastes $(144,520 \mathrm{~kg})$ were used as raw materials for its stabilization under the aerated static pile (ASP) method as an alternative to the mechanically mixed windrow method to solve problems of flies and odor nuisance complaints. In a pile of approximately $498 \mathrm{~m}^{3}$, the change in temperature was the main parameter that was evaluated during 49 days of positive forced aeration. Subsequently, a part of the material of the ASP $\left(62 \mathrm{~m}^{3}\right)$ was subjected to a curing period for 44 days recording changes in temperature and humidity. The results of carbon dioxide and volatile ammonia emissions analyses $\left(\mathrm{NH}_{3}\right)$ and of a bioassay to screen for the presence of phytotoxic conditions showed a very mature compost with an emergence $>$ $90 \%$ and a seedling vigor $>95 \%$.
\end{abstract}

\section{Keywords}

Aerated Static Pile, Composting, Compost

\section{Introduction}

Composting is a dynamic process in terms of the interactive factors of temperature, oxygen, moisture, and nutrient availability all of which affect the microbial population responsible for the biodegradation process. Composting is predominantly an aerobic process. Failure to provide sufficient oxygen for aerobic degradation by microbes results in the slow degradation of organic matter. Proper 
aeration is a key environmental factor. Microorganisms need oxygen to produce energy, grow quickly, and consume more materials. Aeration involves the replacement of oxygen deficient air in a compost pile with fresh air containing oxygen. Natural aeration occurs when air warmed by the composting process rises through the pile bringing in fresh air from the surroundings. Aeration can also be affected by wind, moisture content, and porosity. For static pile composting, the air can be supplied by a pressure system with the blower pushing the air into the pile. The process can be controlled directly using blowers and larger piles can be created. The composting process with aerated static pile method is faster and results in higher quality composts [1]. The objective of the present work was to evaluate the aerated static pile composting method as an alternative to the mechanically mixed windrow composting method with the goal of eliminating fly problems and reducing odor nuisance complaints in the composting of food and yard wastes.

\section{Materials and Methods}

\subsection{Raw Material}

Yard waste $(144,520 \mathrm{~kg})$ was crushed in a hammer mill with a screen of $7.5 \mathrm{~cm}$ and mixed with food waste $(149,690 \mathrm{~kg})$ from industrial canteens and the food industry.

\subsection{Positive Aerated Static Pile (ASP) Construction}

The pile formation was carried out with a front loader on a network of perforated pipes (Figure 1). This pipe network was made up of a 6-inch tube, $4.5 \mathrm{~m}$ long that fed air to 4 pipes, each $24 \mathrm{~m}$ long, joined by a reducer coupling [2]. The air supply was provided by a 2 HP blower with a maximum air volume of 40.49 $\mathrm{m}^{3} / \mathrm{min}$ (B-Air ${ }^{\circledR}$ super bear BP-2+). The perforation of the tubes consisted of two rows of perforations, $0.95 \mathrm{~cm}$ per hole, placed in parallel to each other, 5.8 $\mathrm{cm}$ from the surface of the tubes. The distance between perforations was $15 \mathrm{~cm}$ [3]. Before the formation of the pile, a layer of reject material $(15-20 \mathrm{~cm}, 1 \mathrm{~cm}$ opening screen) was placed on the ground level of the composting screening process. With this same material, the tubes were covered with perforations downwards with a layer of some $15 \mathrm{~cm}$ before forming the pile [2]. Since the raw material was not enough to form a projected pile of $10 \mathrm{~m}$ wide, $24 \mathrm{~m}$ long and 3 $\mathrm{m}$ high in a single stage, the first two tubes were covered in the first stage and then 7 and 14 days later were covered the third and fourth tubes respectively. At the end of forming the pile in its three stages, the material was covered with an approximate layer of reject material $(15-20 \mathrm{~cm})$.

For the measurement of temperature changes, as the pile was formed,16 thermocouples were placed along tubes 1, 2 and 4 and along the tube 3, 4 thermocouples were located, one half of them at an approximate height of $1 \mathrm{~m}$ and the other at a height of approximately $2 \mathrm{~m}$.

At the end of 7 weeks of composting for tubes 1 and 2, 6 weeks on tube 3, and 5 weeks on tube 4 , approximately $62 \mathrm{~m}^{3}$ were taken to form a curing pile. The 


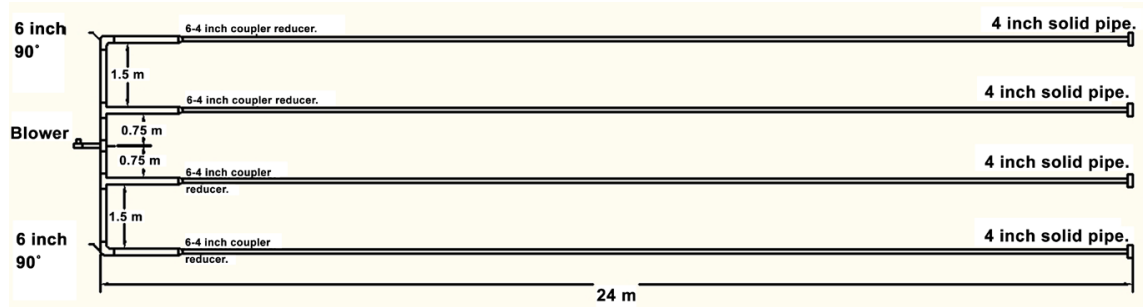

Figure 1. Pipe network for the ASP.

rest of the material completed the process under the windrow composting method (three windrows of $65 \mathrm{~m}$ long, $1.75 \mathrm{~m}$ width and $1.10 \mathrm{high}$ ) with a tractor-assisted windrow turner.

\subsection{Curing Pile}

A portion of the ASP material was screened through an aperture mesh of 2.54 $\mathrm{cm}$, and used to form a pile of approximately $62 \mathrm{~m}^{3}(2.44 \mathrm{~m}$ in height and $9.86 \mathrm{in}$ diameter) for the curing period. In this pile, 5 heavy duty compost thermometers (60 $\mathrm{cm}$ steam) were placed in different places to measure the temperature over 44 days. At days 3, 6, 8, and 16 of maturation, composite samples were taken for moisture analysis, turning and moistening the pile the next day. On days 24,28 , and 31, the pile was turned over and composite samples were taken for moisture analysis without having moistened the pile the next day (Figure 5). After 44 days of curing, a composite sample was taken from the pile for the maturity analysis, seedling emergence, and relative growth [4] and stability [5].

\subsection{Physico-Chemical Analysis}

At the beginning of the pile formation, the mixture of yard and food wastes was analyzed by its content of moisture, total organic carbon (TOC), total Kjeldahl nitrogen (TKN), dry matter, ash, volatile solids, bulk density, and free air space. Moisture content (\%ww) was determined after drying to a constant weight in a ventilated oven at $105^{\circ} \mathrm{C}$ for $24 \mathrm{~h}$. Volatile solids (\%dw) was determined by the percentage ignition loss of dry solids at $550^{\circ} \mathrm{C}$ in a muffle furnace (Terlab). TKN was determined by the macro-Kjeldahl procedure [6]. TOC content was calculated by the following equation [7]:

$$
\% \text { TOC }=(100-\% \text { ash residue }) / 1.8
$$

Bulk density refers to the ratio of the total weight (mass) raw material or compost to its volume, on an as-is basis that was calculated as followed: an empty $20 \mathrm{~L}$ bucket was weighed (recording the weight) and filled $1 / 3$ full with feedstock. The bucket was raised $1.5 \mathrm{~m}$ above a firm surface and allowed to drop 10 times, then the bucket was filled to the $2 / 3$ line with additional material and raised $1.5 \mathrm{~m}$ above the surface and dropped 10 times. The bucket was then filled completely and the dropping sequence was repeated. The bucket was refilled completely (without dropping) and weighed with the material. Bulk density was reported as $\mathrm{kg} / \mathrm{m}^{3}$. To measure free air space, the same bucket and materials 
were used. This test uses water to approximate the amount of voids (free air space) in a bucket full of feedstock. The bucket was filled with water completely without overflowing and weighed. The free air space expressed in \% was calculated as: (L of water that filled the spaces) (100)/volume of the bucket in L [8].

\section{Results and Discussions}

\subsection{Temperature}

The temperature distribution within the composting pile was related to the composting time (Figures 2-4). These temperatures were monitored $1 \mathrm{~m}$ and 2 $\mathrm{m}$ above the ground and represent the average of the thermocouples placed inside the ASP. Throughout the composting, a temperature gradient was formed between the upper and lower layers, a typical phenomenon of a positively ASP [1]. The gradient is a function of air flow rate and direction of air flow and the reactivity of the composting mass. As cool ambient air was passed through the bottom of the pile, this area cooled more rapidly than the top where the heat accumulated.

Figure 2 shows the distribution of the temperature during 7 weeks of the composting material that covered tubes 1 and 2. The ASP experienced a rapid temperature increase in both layers ( 1 and $2 \mathrm{~m}$ above ground). In the upper layer, the temperature rose above $79^{\circ} \mathrm{C}$ at day 13 and $78^{\circ} \mathrm{C}$ on day 7 in the lower layer. After those days the temperature started to drop, falling to $49^{\circ} \mathrm{C}$ in the lower layer and $60^{\circ} \mathrm{C}$ in the upper layer. Five days before the experiment was finished, there was a problem with the electricity supply so no oxygen was supplied, which is why in the lower layer a temperature increase from $49^{\circ} \mathrm{C}$ to $68^{\circ} \mathrm{C}$ was recorded. The temperature of the upper layer apparently was not affected by this lack of electricity since the temperature at the end of the experiment was $58^{\circ} \mathrm{C}$.

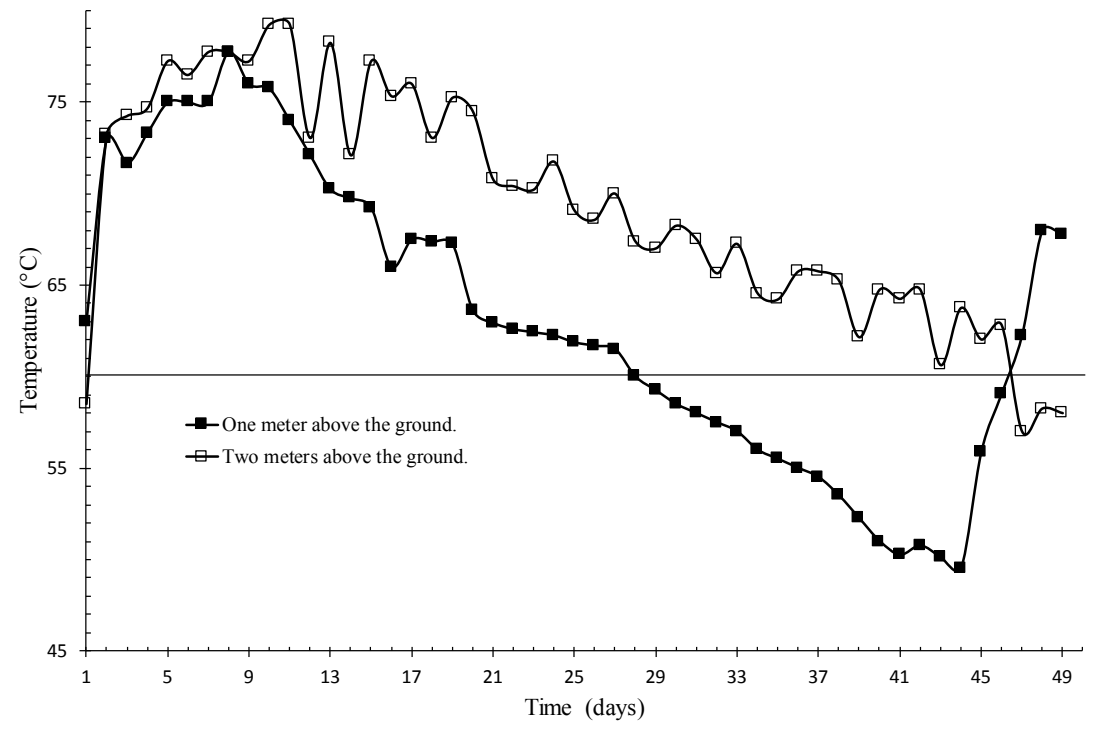

Figure 2. Temperature profiles for the pipes 1 and 2 in the ASP. 


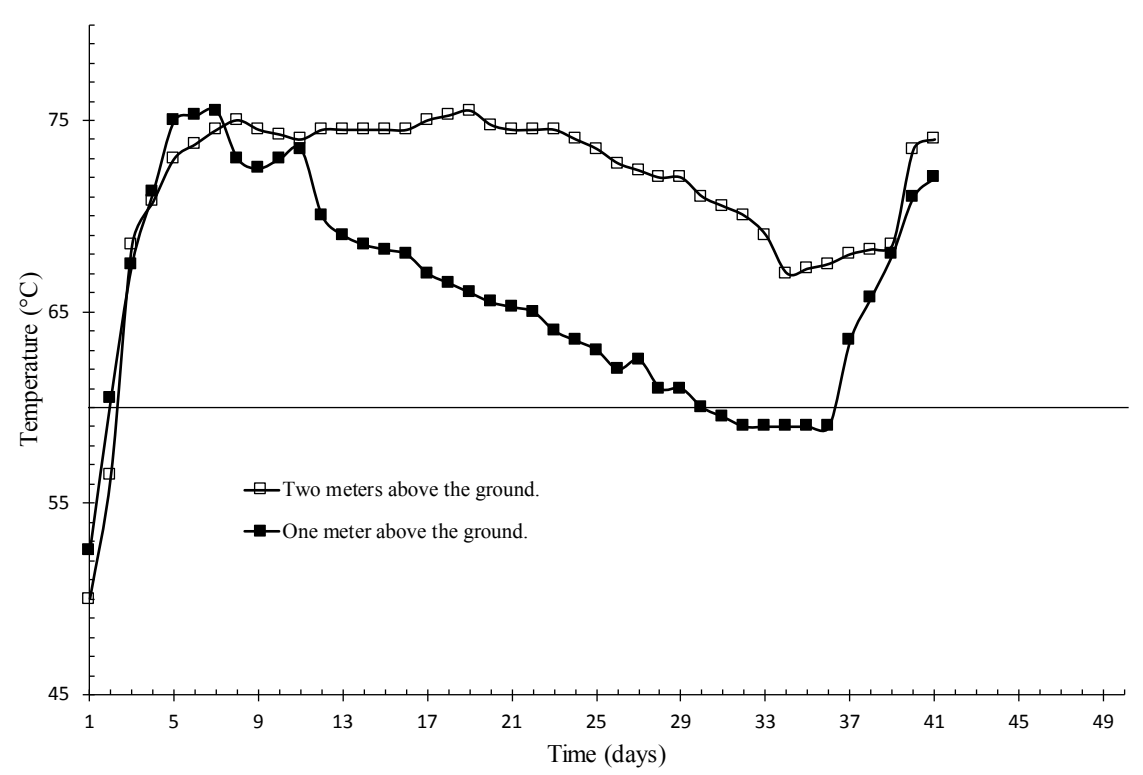

Figure 3. Temperature profiles for the pipes 3 in the ASP.

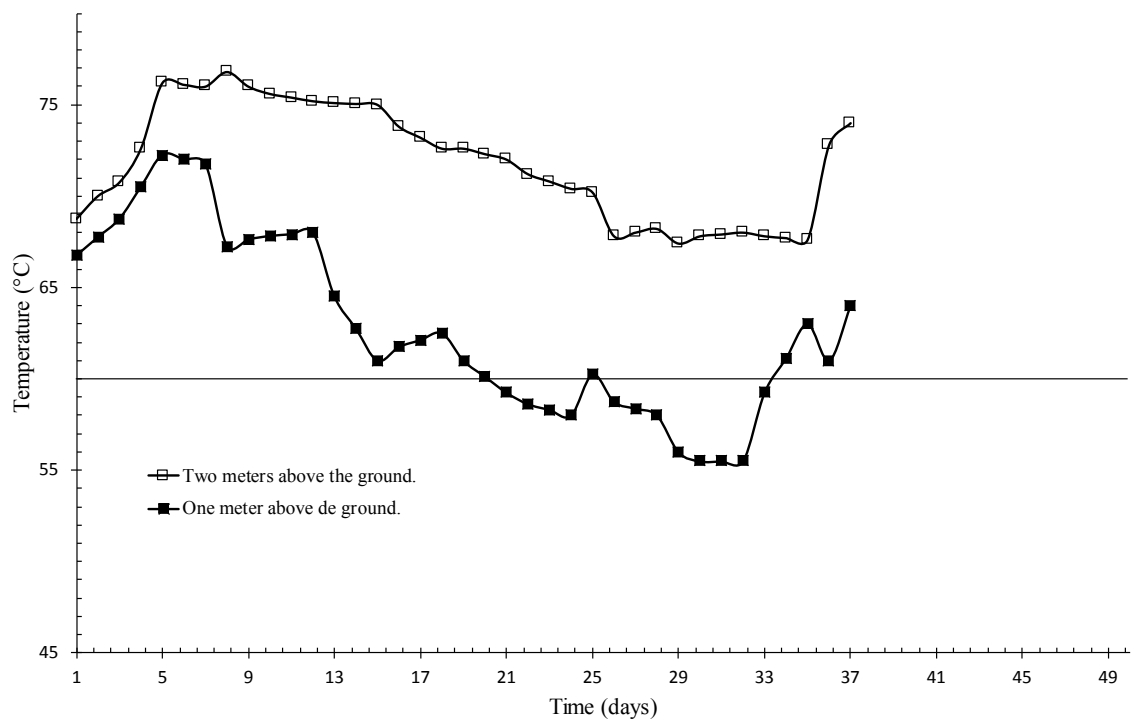

Figure 4. Temperature profiles for the pipes 4 in the ASP.

Figure 3 shows the distribution of the temperature over 6 weeks for the composting material that covered tube 3 . The ASP underwent a rapid temperature increase in both layers ( 1 and $2 \mathrm{~m}$ above ground). In the upper layer, the temperature increased from $50^{\circ} \mathrm{C}$ to $75^{\circ} \mathrm{C}$ in the first 7 days or composting and in the lower layer from $52^{\circ} \mathrm{C}$ to $76^{\circ} \mathrm{C}$ in the first 6 days, after which the temperature started to drop until day 32 when the temperature registered to $59^{\circ} \mathrm{C}$. In the upper layer, the temperature remained constant at about $74^{\circ} \mathrm{C}$ until day 23 when it decreased progressively to $67^{\circ} \mathrm{C}$ by day 33. As with tubes 1 and 2 , when the electricity failed at the end of the experiment, temperature changes were drastically changed from $63^{\circ} \mathrm{C}$ to $72^{\circ} \mathrm{C}$ in the last 5 days in the lower layer and in the upper layer from $68^{\circ} \mathrm{C}$ to $74^{\circ} \mathrm{C}$ in the last 3 days. 
Figure 4 shows the distribution of the temperature during 5 weeks of the composting material that covered the tube 4. As in tube 1 and 2 and tube 3 the ASP experienced a rapid temperature increase in both layers ( 1 and $2 \mathrm{~m}$ above ground), in the upper layer temperature rose from $69^{\circ} \mathrm{C}$ to $77^{\circ} \mathrm{C}$ by day 7 . In the lower layer, the temperature rose from $67^{\circ} \mathrm{C}$ to $72^{\circ} \mathrm{C}$ by day 4 , after which the temperature started to drop in the upper layer to $68^{\circ} \mathrm{C}$ at day 25 and in the lower layer to $56^{\circ} \mathrm{C}$ at day 28. As in tubes 1 and 2 and tube 3 , the lack of ventilation due to electrical failure in the last 5 days of experimentation caused the temperature of the lower layer to increase from $55^{\circ} \mathrm{C}$ to $64^{\circ} \mathrm{C}$ and in the upper one from $68^{\circ} \mathrm{C}$ to $74^{\circ} \mathrm{C}$. The very high temperatures recorded in the positive ASP was a point of concern as the temperatures in excess of $45^{\circ} \mathrm{C}$ to $60^{\circ} \mathrm{C}$ have been shown to negatively affect microbial biomass and activity [9] [10]. In Figures 2-4, it is evident that the temperature of the upper layer of the pile's material that covered the four tubes was above $60^{\circ} \mathrm{C}$ throughout the experimentation period, and the temperature of the lower layer of the pile's material that covered tubes 1 and 2 (Figure 2), tube 3 (Figure 3) and tube 4 (Figure 4) was above $60^{\circ} \mathrm{C}$, at the $57 \%$, $82 \%$ and $61 \%$ of the composting time, respectively. Very high temperatures are highly selective towards a limited group of aerobic heterotrophic and thermophilic microorganisms carrying out the decomposition, stopping the activity of actinomycetes, fungi, and non-thermotolerant microorganisms. With only a few thermophilic bacteria capable of surviving at these high temperatures $\left(>70^{\circ} \mathrm{C}\right)$, microbial transformation of long chain polymers such a cellulose, hemicellulose and lignin, plentiful in gardening wastes and tree prunings, is slowed [11]. This process is essentially carried out by mesophilic fungi and actinomycetes [12].

\subsection{Moisture Content}

The average moisture content determined in several samples of the raw material was $55 \%$. After 7 weeks of composting, the moisture content of the material covering tubes 1 and 2 was 42.5\%. After 6 weeks of composting, the material covering the tube 3 had a moisture content of $45 \%$ and for the material that covered the tube 4 after 5 weeks of composting, the moisture content was $47 \%$. Moisture content between $40 \%-60 \%$ is ideal for compost under aerobic conditions [13]. Adequate moisture is needed for microbial respiration that is responsible for the decomposition of waste material in compost. Too little water will deactivate microorganisms, whereas too much water favors anaerobic microbes that produce fermentation. Anaerobic conditions slow decomposition and may produce bad odors, noxious gases, and phytotoxic acids, lowering the quality of compost.

Bulk density refers to the ratio of the total weight (mass) of compost or ingredients for composting and this optimal range value must be $475-712 \mathrm{~kg} / \mathrm{m}^{3}$. In our case the mixture of yard and food waste had an average value of 600 $\mathrm{kg} / \mathrm{m}^{3}$. Bulk density is needed to convert compost recipes from weight to a volume basis for field mixing. The amount of moisture in compost ingredients 
strongly affects bulk density, with wetter materials having a higher bulk density compared to dry materials. As such, bulk density of compost or ingredients is always calculated on a wet basis [13].

Porosity refers to the amount of air-filled pore space in compost that is not occupied by solid particles or water. Porosity is expressed as a percentage of the total bulk volume of the compost pile. An adequate supply of oxygen is needed for microbial respiration in aerobic decomposition. Aeration provides oxygen and stimulated the removal of heat, water vapor, and gases during the active composting phase. An optimal air-solid balance is achieved when the fee air space (porosity) in the pile is in the $35 \%-60 \%$ range [13]. In our case, the mixture of yard and food waste had an average value of $44 \%$.

$\mathrm{C}: \mathrm{N}$ ratio. The bacteria and fungi that decompose organic matter require carbon and nitrogen to grow and reproduce. Carbon serves the dual purpose of an energy source for cellular respiration and as an element in the cell protoplasm. Consequently, much more carbon is needed for cellular increase, compared to nitrogen. Nitrogen is a crucial component of the proteins, nucleic acids, amino acids, enzymes, and co-enzymes that are necessary for cell growth and function. Target range of C:N ratio must be 20:1 - 40:1 [3].

\subsection{Curing Period}

Following active composting, compost requires a curing period of at least one month to finish the process and allow the compost to develop the desired characteristics for its intended use. Figure 5 shows the temperature changes of the compost pile in the curing period during 44 days and the days when it was moved to aerate it and add water. At the beginning of this period, the temperature of the pile was $53^{\circ} \mathrm{C}$ and the moisture content $28.5 \%$, so on day 4 water was added to reach a $38.3 \%$ moisture content, as this water was not enough to

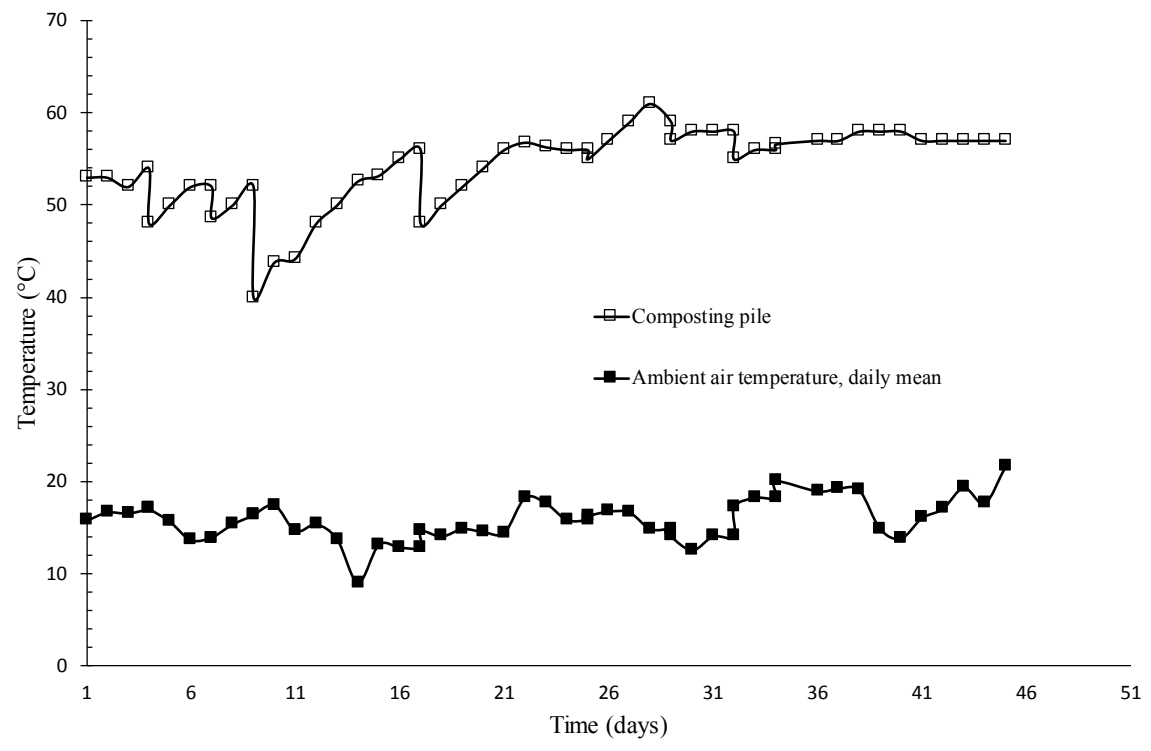

Figure 5. Temperature profiles of the composting pipe in the curing period. 
achieve $60 \%$ of humidity. On day 7 water was again added to reach a humidity content of $41.4 \%$. On days 9 and 17, the pile was moved again and water added, registering water contents of $44.5 \%$ and $42 \%$, respectively. On days $25,29,32$, and 34, no more water was added to the pile, and it was only turned with a front loader since the humidity was no longer less than $41 \%$ until day 44 when the material of the pile became a blackish color, smelling of wet earth. The water content in the composting is recommended between $40 \%$ - 65\% [3] since this range is essential for the microbial activity and can affect the decomposition rate. If the water content is less than $40 \%$, the microbial activity is reduced; if it is greater than $60 \%$, the water fills the spaces required for air movement, so that anaerobic conditions occur [13] [14]. During the curing period, the maximum temperature range without moving the pile was $53^{\circ} \mathrm{C}-58^{\circ} \mathrm{C}$ values within the ideal range for thermophilic aerobic composting. However, despite these high temperatures, the maturity of the compost was achieved after 44 days according to the stability and maturity tests. The height of the curing pile $(2.44 \mathrm{~m})$ was built according to maximum pile height of $2.4 \mathrm{~m}$, as is often suggested [3].

The results of the Solvita test to measure the two most prominent gaseous emissions of active composts (carbon-dioxide, $\mathrm{CO}_{2}$ and volatile ammonia, $\mathrm{NH}_{3}$ ) showed that after an active composting phase of 7 - 5 weeks under an ASP system and 44 days of a curing period in a static pile with periodic movement and wetting, a stable compost was obtained. The bioassay results to screen for the presence of a phytotoxic condition showed that for the compost of the maturation pile as well as for the windrows, the product was a very mature compost with an emergence $>90 \%$ and a seedling vigor $>95 \%$.

\section{Conclusion}

The implementation of the ASP composting method with a biofilter layer in the composting plant "El Morado" S.A. de C.V. resulted in several advantages: 1) the flies problem was eliminated; 2) odor nuisance complaints were substantially reduced; and 3) the owner of the company preferred and selected the ASP system, as opposed to the system of mechanically mixed windrow composting, because ASP requires neither a tractor-drawn turner nor a large expanse of land.

\section{Acknowledgements}

Thanks to the Agronomist Engineer Efrain Aguirre Macías, owner of the composting company "El Morado Compost S.A. de C.V.", for all the support provided for the realization of this Project. Engineer Efraín is an exemplary entrepreneur.

\section{Conflicts of Interest}

The authors declare no conflicts of interest regarding the publication of this paper.

\section{References}

[1] Stentiford, E.I. (1996) Composting Control: Principles and Practice. In: De Bertoldi, 
M., Sequi, P., Lemmes, B. and Papi, T., Eds., The Science of Composting, Blackie Academic and Professional, London, 49-59. https://doi.org/10.1007/978-94-009-1569-5_6

[2] Moon, P. (2013) Aerated Composting Systems Webinar (8/20/13). https://www.youtube.com/watch?v=AQnp-FUNX4A

[3] Rynk, R., van de Kamp, M., Wilson, G.G., Singley, M.E., Richard, T.L., Kolega, J.J., Gouin, F.R., Laliberty Jr., Kay, D., Murphy, D., Hoitink, H.A.J. and Briton, W.E. (1992) On-Farm Composting Handbook. Rynk, R., Ed. Natural Resources, Agriculture, and Engineering Service, Ithaca, NRAES-54.

[4] TMECC (2001) Test Methods for the Examination of Composting and Compost. https://compostingcouncil.org/wp-content/plugins/wp-pdfupload/pdf/34/TMECC \%20Purpose,\%20Composting\%20Process.pdf

[5] Solvita and Woods End Laboratories (2018) Solvita. Compost Maturity Testing in Your Hands, On-Site. https://solvita.com/compost/

[6] AOAC (1990) Official Methods of Analysis. 12th Edition, Association of Official Analytical Chemists, Washington DC, 11-18.

[7] Golueke, C.G. (1977) Biological Processing: Composting and Hydrolysis. In: Wilson, D.G., Ed., Handbook of Solid Waste Management, Reinhold van Norstrand, New York, 195-225.

[8] United States Composting Council (USCC) (2015) USCC Compost Operations Training Course.

http://compostingcouncil.org/wp/wp-content/uploads/2015/09/7-Moisture-Bulk-D ensity-Field-Exercise-2015.pdf

[9] McKinley, V.L. and Vestal, J.R. (1985) Effects of Different Temperature Regimes on Microbial Activity and Biomass in Composting Municipal Sewage Sludge. Canadian Journal of Microbiology, 31, 919-925. https://doi.org/10.1139/m85-172

[10] Strom, P.F. (1985) Identification of Thermophilic Bacteria in Solid-Waste Composting. Applied and Environmental Microbiology, 50, 906-913.

[11] de Bertoldi, M., Vallini, G. and Pera, A. (1983) The Biology of Composting: A Review. Waste Management and Research, 1, 157-176.

https://doi.org/10.1177/0734242X8300100118

[12] de Bertoldi, M., Rutili, A., Citterio, B. and Civilini, M. (1988) Composting Management: A New Process Control through $\mathrm{O}_{2}$ Feedback. Waste Management Research, 6, 239-259. https://doi.org/10.1177/0734242X8800600141

[13] Walters, R. (2016) Technical Note 24. Composting Basics: Bulk Density, Moisture, Porosity.

http://open-furrow-agrosphere.net/Documents/DHC/Composting_Basics1.pdf

[14] Epstein, E. (1996) The Science of Composting. CRC Press, Boca Raton, 487 p. 